\title{
Bankruptcy Prediction Models and Stock Prices of the Coal Mining Industry in Indonesia
}

\author{
Ghazali Syamni', M. Shabri Abd. Majid'2, Widyana Verawaty Siregar ${ }^{3}$
}

\begin{abstract}
Various bankruptcy prediction models have been used to measure the movement of stock prices, and thus the firms performance. This study is aimed at empirically exploring the usefulness of the Olhson, Almant Modification, Grover, Springate, and Zmijewski models for predicting bankruptcy of the 19 coal mining companies. It also attempts to measure the effects of the scores of these bankruptcy prediction models on the stock prices of the coal mining companies in Indonesia. The technique of analysis that used in this research is panel regression. The results of the study showed that the bankruptcy prediction scores of the Ohlson and Almant Modification were found to be the dominant prediction models that affected the stock prices of the coal companies in Indonesia. This indicates that the bankruptcy prediction model can be used as one of the approaches to measure the movement of stock prices and performance of the coal mining companies in Indonesia.
\end{abstract}

Keywords: bankruptcy, stock prices, coal mining companies.

\begin{abstract}
Abstrak. Berbagai model prediksi kebangkrutan telah digunakan untuk mengukur pergerakan harga saham dan sekaligus kinerja perusahaan. Penelitian ini bertujuan untuk mengeksplorasi secara empiris kegunaan model Olhson, Almant Modification, Grover, Springate, dan Zmijewski dalam memprediksi kebangkrutan 19 perusahaan pertambangan batubara. Penelitian ini juga menguji dampak model prediksi kebangkrutan terhadap harga saham perusahaan pertambangan batubara di Indonesia. Teknik analisis yang dipergunakan pada penelitian ini ialah teknik regresi panel. Hasil penelitian ini menemukan bukti bahwa model prediksi Ohlson dan Modifikasi Almant merupakan model prediksi dominan yang mempengaruhi harga saham perusahaan batubara di Indonesia. Hal ini mengindikasikan bahwa model prediksi kebangkrutan dapat digunakan untuk memprediksikan pergerakan harga saham dan sekaligus kinerja keuangan industri batubara di Indonesia.
\end{abstract}

Kata kunci: kebangkrutan, harga saham, perusahaan pertambangan batubara

\section{How to Cite:}

Syamni, G., Majid, M.S.A., \& Siregar, W.F. (2018). Bankruptcy Prediction Models and Stock Prices of The Coal Mining Industry in Indonesia. Etikonomi: Jurnal Ekonomi. Vol. 17 (1): 57 - 68. doi: http//dx.doi.org/10.15408/etk.v17i1.6559. 


\section{Introduction}

Various approaches have been adopted to measure the company financial performances; one of them is using the bankruptcy prediction models. The bankruptcy prediction model has been used to analyze the company performances of different industries. The first bankruptcy prediction model was introduced by Altman (1968), known as Almant Z-Score. This model has been widely used and still being relevant to predict a company whether it is bankrupt, in grey area or healthy (Altman, et al, 2017). In 1995, Edward Almant later modified the model, so that it can be used for predicting bankruptcy of manufacturing and non-manufacturing companies.

After 1970s, several other models have been introduced to predict bankruptcy such as Springate (1978); Ohlson (1980); Zmijewski (1983); and Grover and Lavin (2001). The names of the models were given based on the name of the researchers who introduced them for the first time. In his study, Jayasekera (2017) have identified four models of the bankruptcy prediction, namely: the mathematic, neural network, statistic and the market models. Meanwhile, Wu, et al (2010) categorized the bankruptcy models into the discriminant model popularized by Altman in 1968, the logit model introduced by Ohlson in 1980, the probit model developed by Zmijewski in 1984, the hazard model proposed by Shumway in 2001, and the Black-Scholes-Merton (BSM) probability model introduced by Hillegeist, et al (2004).

In predicting the bankcruptcy, these models have different levels of accuracy based on their measurements used (Purnajaya and Merkusiwati, 2014). For example, the Ohlson model has added the company income variable and in totality, the model has seven variables. Meanwhile, the modified Almant and Springate models have the similar four variables to the Olson model, yet they have different types of variables, except the working capital of the total assets. Finally, the models categorized the firm either into the healthy, grey area, or bankrupted company with different scores. The detailed measurements of the models are explained in the methodological section.

Many previous empirical studies in the developed countries have used different models to predict the company performances. For example, in the United States of America; Charitou, et al (2013) used the Black-Scholes-Merton (BSM) model to predict the bankruptcy of the non-financial companies. In England, Tinoco and Wilson (2013) predicted the bankruptcy by using the network and Almant Z Score models. Ko, et al (2017) predicted the bankruptcy of the solar energy company in Taiwan using the Z score model. Xu and Zhang (2009) predicted the bankruptcy of the listed companies in the Japanese stock exchange using the Almant $Z$ and the Ohlson scores and then regressed them with the financial performances of the bank institution and Keiretsu firms as the dependent variable.

Similar studies on the bankruptcy prediction in the developing countries have also used different types of the bankruptcy prediction models. Marcinkevičius and Kanapickienè (2014) predicted the bankruptcy of the construction company in Lithuania using the Altman, Springate, Taffler and the Tisshaw models. Karas and Režňáková (2015) measured the bankruptcy prediction of manufacturing company in the Republic of Czech 
using the combining models of the discriminant and the Box Cox. In Saudi Arabia, AlKassar and Soileau (2014) predicted the bankruptcy of different companies (i.e., the mill, transportation, heritage and museum, commercial companies, and the replenishment of oil companies) using the Z-score model. Similarly, using the Z score model, Hussain, et al (2014) measured bankruptcy of the textiles industry in Pakistan, while Al-Rawi, et al (2011) investigated the bankruptcy of the glassware company in Jordan. Karamzadeh (2013) predicted the bankruptcy of 90 stock exchange companies in Teheran using the Almant Z score and the Ohlson models. In Thailand, Pongsatat, et al (2004) using the Almant and Ohlson models to predict the performances of 60 bankrupted companies and 60 non-bankrupted companies.

In the context of Indonesia, in predicting the bankruptcy of the companies, many previous studies have widely used a single Almant Z Score (Sudiyatno and Puspitasari, 2010), while only few other studies used different types of the bankruptcy prediction models for companies of different sectors. For example, Sembiring (2016) used the Ohlson model to predict the bankrupted companies. In predicting the bankruptcy, Rachmawati (2016) applied the Almant model for the insurance company, Boedi and Tiara (2016) for the telecommunication company, and Yunan and Rahmasari (2015) for Shariah Stock Performance.

On the other hand, the previous studies that used more than one models for predicting the bankruptcy of the company in Indonesia. Putera, et al (2017) predicted the bankruptcy of the mining companies by using the Altman, Springate and Ohlson models. Gunawan, et al (2016) applied the Altman, Grover and Zmijewski models for the manufactures company, while Rahayu, et al (2016) used the Altman Z-Score, Springate, and the Zmijewski models for the telecommunication companies in Indonesia.

Furthermore, Effendi, et al (2016) used the bankruptcy prediction model of the Springate to estimate the stock prices of the telecommunication companies, while Andriawan and Salean (2016) used the Almant model and analyzed its impact to the pharmacy company's stock prices. Adrian and Khoiruddin (2014) applied the Almant model and analyzed its impact to the manufacturing company's stock prices. They documented that the Almant model affected the stock prices of the manufacturing companies (Adrian and Khoiruddin, 2014), the pharmacy companies (Andriawan and Salean, 2016), and the transportation companies (Amaliawiati and Lestari, 2014) in Indonesia. Effendi et al. (2016) found that the Springate model affected the stock prices, while Wulandari and Norita (2014) found that the Ohlson model (O-score) affected the stock returns of the textile and garment companies in Indonesia over the period 2010-2014. In short, these studies only used a single bankruptcy prediction model to estimate the stock prices in Indonesia.

The above-reviewed studies showed that many previous empirical studies have only adopted a single model to predict the performance of the firm, and yet its connection to the stock prices was rarely done using various bankcruptcy prediction models, thus provided insufficient empirical findings. Bankruptcy prediction models might affect the stock prices, indicating that when a company goes into bankruptcy, its stock price goes down or unchanged. 
Relying only on a single model to predict the bankcruptcy might lead to an inaccurate estimation, thus it, in turns, lead to the improper policy recommendation. Anticipating this, the present study used various models to predict the bankruptcy of the firms and analyzed its impact to the firms' stock prices in Indonesia. Thus, this study is among the first to use various bankruptcy models of the Olhson, Almant Modification, Grover, Springate, and the Zmijewski to estimate the stock prices in the Indonesian stock markets. This is the first novelty of this study that is in its comparison among the bankruptcy prediction models. Estimating comparatively among these models would show the most suitable and accurate model to be adopted to predict the movement of stock prices in Indonesia. Secondly, this study focuses its analysis on the coal mining companies, which has no previous empirical studies on this important industry in the Indonesian economy. Considering the shortcomings and mixed or inconclusive empirical findings of the previous studies on the relationships between the bankruptcy prediction models and stock prices in Indonesia, thus this study is hoped to provide a more comprehensive and enriching empirical evidences on this issue by comparing various bankruptcy prediction models (i.e., the Olhson, Almant Modification, Grover, Springate, and the Zmijewski models) and then analysing its impact to the stock prices of the coal mining industry in Indonesia.

The findings of this study are hoped to shed some lights for the inventors when selecting which companies to invest the monies, for the managers to promote the performance of the companies, and for the regulator to design policy in enhancing the stock market in the biggest Muslim populous country in the world, Indonesia. The rest of this study is structured as follows. Section 2 provides the empirical framework and followed by the discussion of the findings and their implications in Section 3. Finally, Section 4 concludes the study.

\section{Method}

Data of this study is gathered from the financial report of 19 companies in the coal mining sector that are listed on the Indonesian Stock Exchange (IDX) over the period 2013 to 2015. These data are accessed through the website www.idx.co.id and firms are selected using the purposive sampling technique. The firms investigated in this study are the coal mining company that published their audited financial reports during the period 2013-2015. As for the stock prices, the closing stock prices of 19 coal-mining companies are used.

To predict the bankruptcy of the companies, the bankruptcy prediction models of the Olhson, Almant Modification, Grover, Springate, and the Zmijewski are used. The formula, description, and score categorization for each model are presented in Table 1.

After measuring the scores for each bankruptcy prediction model, in the next step, the panel regression model is estimated to explore the impacts of bankruptcy prediction models to the stock prices of the coal mining companies in Indonesia. The scores of five bankruptcy prediction models investigated in this study are then treated as the independent variables to predict the stock prices. 
This panel regression model is the most appropriate model to adopt in this study since the study utilizes the aggregated data of time series and cross section data over the period 2013 to 2015. The following multiple panel regression model is estimated:

$$
\mathrm{LnSP}_{\mathrm{it}}=\alpha+\beta_{1} \mathrm{OS}_{\mathrm{it}}+\beta_{2} \mathrm{ZM}_{\mathrm{it}}+\beta_{3} \mathrm{GS}_{\mathrm{it}}+\beta_{4} \mathrm{SS}_{\mathrm{it}}+\beta_{5} \mathrm{ZS}_{\mathrm{it}}+\varepsilon_{\mathrm{it}}
$$

Where LnSP is the natural logarithm of stock prices, OS is the Olson Score, ZM is the Modified Altman-Z-Score, GS is the Grover Score, SS is the Springate Score, ZS is the Zmijewski Score, $\varepsilon$ is the error term, $i$ and $t$ is representing firm $i$ for year $t$.

Table 1. The Bankruptcy Prediction Models

\begin{tabular}{|c|c|c|c|c|}
\hline No. & Model & Formula & Description & Score Category \\
\hline 1. & $\begin{array}{l}\text { Springate } \\
\text { (1978) }\end{array}$ & $\begin{array}{l}S S=1,03 X_{1}+3,07 X_{2} \\
\quad+0,66 X_{3}+0,4 X_{4}\end{array}$ & $\begin{array}{l}\text { SS }=\text { Springate } \text { Score } \\
\mathrm{X}_{1}=\text { Working capital/Total asset } \\
\mathrm{X}_{2}=\text { Net profit before interest taxes/ } \\
\text { total } \\
\quad \text { asset } \\
\mathrm{X}_{3}=\text { Net profit before Taxes/Current } \\
\quad \text { liabilities } \\
\mathrm{X}_{4}=\text { Sales/Total asset }\end{array}$ & $\begin{array}{l}\text { SS }>0,862=\text { healthy } \\
\text { SS }<0,862=\text { bankrupt }\end{array}$ \\
\hline 2. & $\begin{array}{l}\text { Ohlson } \\
(1980)\end{array}$ & $\begin{array}{l}\text { OS }=-1,32-0,407 X_{1}+ \\
6,03 X^{2} \\
-1,43 X_{3}+0,0757 X_{4} \\
-2,37 X_{5}-1,83 X_{6}+ \\
0,285 X_{7} \\
-1,72 X_{8}-0,521 X_{9}\end{array}$ & $\begin{array}{l}\text { OS }=\text { Ohlon Score } \\
X_{1}=\text { Log (total assets/GNP index) } \\
X_{2}=\text { Total liabilities/total assets } \\
X_{3}=\text { Working capital/total assets } \\
X_{4}=\text { Current liabilities/current assets } \\
X_{5}=1 \text { if total liabilities }>\text { total assets; } 0 \text { if } \\
\text { otherwise } \\
X_{6}=\text { Net income/total assets } \\
X_{7}=\text { Cash flow from operations/total } \\
\quad \text { liabilities } \\
X_{8}=1 \text { if Net income negative } ; 0 \text { if } \\
\text { otherwise } \\
X_{9}=(\text { NIt }- \text { NIt-1) / (NIt }+ \text { NIt- } 1)\end{array}$ & $\begin{array}{l}\text { OS }>0,38=\text { bankrupt } \\
\text { OS }=0,38=\text { grey area } \\
\text { OS }<0,38=\text { healthy }\end{array}$ \\
\hline 3. & $\begin{array}{l}\text { Zmijewski } \\
(1983)\end{array}$ & $\begin{aligned} Z & =-4,3-4,5 X_{1}+5,7 X_{2} \\
& -0,004 X_{3}\end{aligned}$ & $\begin{array}{l}\mathrm{ZS}=\text { Zmijewski Score } \\
\mathrm{X}_{1}=\mathrm{ROA} \text { (Net income/ total assets) } \\
\mathrm{X}_{2}=\text { Leverage (Total liabilities/total } \\
\quad \text { assets) } \\
\mathrm{X}_{3}=\text { Liquidity (Current assets/current } \\
\quad \text { liabilities) }\end{array}$ & $\begin{array}{l}Z S>0=\text { bankrupt } \\
Z S<0=\text { health }\end{array}$ \\
\hline 4. & $\begin{array}{l}\text { Grover } \\
(2001)\end{array}$ & $\begin{array}{c}G=1.650 X_{1}+3.404 X_{3} \\
-0.016 R O A+0.057\end{array}$ & $\begin{array}{l}\mathrm{GS}=\text { Grover Score } \\
\mathrm{X}_{1}=\text { Working capital/Total assets } \\
\mathrm{X}_{2}=\text { Earnings before interest and } \\
\text { taxes/Total assets } \\
\text { ROA }=\text { net income/total assets }\end{array}$ & $\begin{array}{l}\mathrm{GS} \leq-0,02=\text { bankrupt } \\
\mathrm{GS} \geq 0,01=\text { health }\end{array}$ \\
\hline 5. & $\begin{array}{l}\text { Modified } \\
\text { Altman- } \\
\text { Z-Score } \\
\text { (1995) }\end{array}$ & $\begin{array}{l}\mathrm{ZM}=6,56 \mathrm{X}_{1}+3,26 \mathrm{X}_{2} \\
\quad+6,72 \mathrm{X}_{3}+1,05 \mathrm{X}_{4}\end{array}$ & $\begin{array}{l}\text { ZM }=\text { Modified Altman- } Z \text {-Score } \\
X_{1}=\text { Working Capital/Total Asset } \\
X_{2}=\text { Retained Earnings/Total Asset } \\
X_{3}=\text { Earnings Before Interest and } \\
\quad \text { Taxes/Total Asset } \\
\text { X4 }=\text { Book value of (Equity/total debt) }\end{array}$ & $\begin{array}{l}Z_{M}<1,10=\text { bankrupt } \\
Z_{M}=1,10-2,60=\text { grey } \\
Z_{M}>2,60=\text { health }\end{array}$ \\
\hline
\end{tabular}

In this study, the Chow Test and Hausman test would be firstly conducted in order to identify the most appropriate model to be used. The Chow test is conducted to select 
between the CEM and the FEM, while the Hausman test is conducted to select between the FEM and REM. If the result of the p-value of Chow test is insignificant, the CEM is selected as the most appropriate model. Similarly, if the Hausman test is insignificant, then, the REM would select as the most suitable panel regression model, and vice versa. Within the FEM framework, the model allows to have a different intercept in the regression model among individual.

\section{Result and Discussion}

The findings of the five bankruptcy prediction models of the Olhson, Almant Modification, Grover, Springate, and the Zmijewski are presented in Table 2. As observed from the table, of the five models, only the Almant modification model provides answers for the three indicators of 19 coal mining companies. Overall, out of 19 companies, only three companies are predicted to be healthy by five models; they are, Golde Energy Mines Tbk, Toba Bara Sejatra Tbk and Indo Tambangraya Megah Tbk. Meanwhile, the Almant model could not predict four companies or these companies are categorized in the grey area. These companies include Adaro Energy Tbk, Baramulti Suksessarana Tbk, Darma Henwa Tbk and Golden Eagle Energy Tbk. In addition, based on the Grover model, 15 companies are predicted in the category of healthy, while the Zmijewski, Almant modification, Springate, and the Olhson models respectively predicted $12,11,8$, and 3 companies in the category of healthy.

Furthermore, using the Ohlson model, 3 companies are found to be healthy (3\%), 16 companies are found to be bankrupt (16\%), and none in the grey area. Thus, it can be concluded that the Ohlson model provides a low prediction because it includes many indicators, including the economic growth variable. The Almant modification model found 10 companies $(11 \%)$ to be healthy $(\mathrm{H}), 4$ companies (3\%) to be bankrupts $(\mathrm{F})$, and 5 companies $(5 \%)$ to be in the grey area $(\mathrm{G})$. Grover models documented 15 Healthy companies (15\%), 4 bankrupted companies (4\%), and none of the company was in the grey area. The Springate found more companies that went bankrupt than the healthy ones, where 10 companies went bankrupt (11\%) and 9 healthy companies (8\%). The Zmijewski model is the second model after Grover model that found more healthy companies, that were 12 companies (12\%); and 7 bankrupted companies (7\%).

The Grover model found the largest number of companies in the healthy category, while the Olhson model documented more firms in the bankruptcy category. Finally, the Modified Almant model found more firms in the grey area category. These findings further imply that the bankruptcy prediction models have different levels of accuracy in predicting the performance of the firms. Thus, in predicting the performance of the firms, the investors, managers, and for policy makers should not only rely on a single bankruptcy model to predict the performance of the firm. 
Table 2.

Predicting Bankruptcy Scores of the Coal Mining Companies in Indonesia, 2013-2015

\begin{tabular}{|c|c|c|c|c|c|c|c|c|c|c|c|}
\hline \multirow[b]{2}{*}{ No } & \multirow[b]{2}{*}{ Company } & \multicolumn{2}{|l|}{ Score } & \multicolumn{2}{|l|}{ Score } & \multicolumn{2}{|l|}{ Score } & Score & \multicolumn{3}{|c|}{ Score } \\
\hline & & Olhson & Pred. & $\begin{array}{l}\text { Mod. } \\
\text { Altman }\end{array}$ & Pred. & Grover & Pred. & Springate & Pred. & Zmijewski & Pred \\
\hline 1 & Adaro Energy Tbk & 0.58 & $\mathrm{~F}$ & 2.59 & $G$ & 0.37 & $\mathrm{H}$ & 0.809 & $\mathrm{~F}$ & -1.67 & $\mathrm{H}$ \\
\hline 2 & Atlas Resources Tbk & 2.72 & $\mathrm{~F}$ & -1.57 & $\mathrm{~F}$ & -0.88 & $\mathrm{~F}$ & -0.638 & $\mathrm{~F}$ & -0.17 & $\mathrm{H}$ \\
\hline 3 & Bara Jaya Internasional Tbk & 0.75 & $\mathrm{~F}$ & 3.07 & $\mathrm{H}$ & 0.56 & $\mathrm{H}$ & 0.733 & $\mathrm{~F}$ & -2.28 & $\mathrm{H}$ \\
\hline 4 & Baramulti Suksessarana Tbk & 17.87 & $\mathrm{~F}$ & 1.19 & G & 0.12 & $\mathrm{H}$ & 0.669 & $\mathrm{~F}$ & 11.40 & $\mathrm{~F}$ \\
\hline 5 & Bumi Resources Tbk & 5.24 & $\mathrm{~F}$ & -9.58 & $\mathrm{~F}$ & -2.32 & $\mathrm{~F}$ & -1.572 & $\mathrm{~F}$ & 4.59 & $\mathrm{~F}$ \\
\hline 6 & Bayan Resources Tbk & 1.68 & $\mathrm{~F}$ & -0.08 & $\mathrm{~F}$ & -0.41 & $\mathrm{H}$ & -0.258 & $\mathrm{~F}$ & 1.07 & $\mathrm{~F}$ \\
\hline 7 & Darma Henwa Tbk & 1.65 & $\mathrm{~F}$ & 1.67 & G & 0.27 & $\mathrm{H}$ & 0.119 & $\mathrm{~F}$ & -1.54 & $\mathrm{H}$ \\
\hline 8 & Delta Dunia Makmur Tbk & 2.64 & $\mathrm{~F}$ & 1.00 & $\mathrm{~F}$ & 0.42 & $\mathrm{H}$ & 0.466 & $\mathrm{~F}$ & 1.43 & $\mathrm{H}$ \\
\hline 9 & Golde Energy Mines Tbk & -0.76 & $\mathrm{H}$ & 5.44 & $\mathrm{H}$ & 0.69 & $\mathrm{H}$ & 0.962 & $\mathrm{H}$ & -3.12 & $\mathrm{H}$ \\
\hline 10 & Toba Bara Sejatra Tbk & 0.19 & $\mathrm{H}$ & 2.62 & $\mathrm{H}$ & 0.67 & $\mathrm{H}$ & 1.315 & $\mathrm{H}$ & -6.24 & $\mathrm{H}$ \\
\hline 11 & Harum Energy Tbk & 2.91 & $\mathrm{~F}$ & 10.77 & $\mathrm{H}$ & 0.80 & $\mathrm{H}$ & 1.194 & $\mathrm{H}$ & -3.84 & $\mathrm{H}$ \\
\hline 12 & Indo Tambangraya Megah Tbk & -0.06 & $\mathrm{H}$ & 6.10 & $\mathrm{H}$ & 0.97 & $\mathrm{H}$ & 1.764 & $\mathrm{H}$ & -3.10 & $\mathrm{H}$ \\
\hline 13 & Resources Alam Indonesia Tbk & 3.81 & $\mathrm{~F}$ & 8.46 & $\mathrm{H}$ & 0.81 & $\mathrm{H}$ & 1.345 & $\mathrm{H}$ & -9.49 & $\mathrm{H}$ \\
\hline 14 & Mitrabara Adiperdana Tbk & 17.49 & $\mathrm{~F}$ & 4.45 & $\mathrm{H}$ & 1.15 & $\mathrm{H}$ & 7.938 & $\mathrm{H}$ & 9.20 & $\mathrm{~F}$ \\
\hline 15 & Samindo Resource Tbk & 13.37 & $\mathrm{~F}$ & 4.22 & $\mathrm{H}$ & 0.90 & $\mathrm{H}$ & 1.291 & $\mathrm{H}$ & 1.70 & $\mathrm{~F}$ \\
\hline 16 & Perdana Karya Perkasa Tbk & 59.34 & $\mathrm{~F}$ & 0.45 & $\mathrm{~F}$ & -54.62 & $\mathrm{~F}$ & -34.12 & $\mathrm{~F}$ & -66.71 & $\mathrm{H}$ \\
\hline 17 & Bumi Asam Tbk & 0.40 & $\mathrm{~F}$ & 6.50 & $\mathrm{H}$ & 1.03 & $\mathrm{H}$ & 1.671 & $\mathrm{H}$ & -2.64 & $\mathrm{H}$ \\
\hline 18 & Petrosea Tbk & 1.78 & $\mathrm{~F}$ & 2.84 & $\mathrm{H}$ & -2.33 & $\mathrm{~F}$ & 0.513 & $\mathrm{~F}$ & 0.34 & $\mathrm{~F}$ \\
\hline 19 & Golden Eagle Energy Tbk & 18.01 & $\mathrm{~F}$ & 2.35 & G & 0.09 & $\mathrm{H}$ & 0.058 & $\mathrm{~F}$ & 22.77 & $\mathrm{~F}$ \\
\hline & Healthy & $3(\%)$ & & $11(\%)$ & & $15(\%)$ & & $8(\%)$ & & $12(\%)$ & \\
\hline & Bankruptcy & $16(\%)$ & & $3(\%)$ & & $4(\%)$ & & $11(\%)$ & & $7(\%)$ & \\
\hline & Grey Area & $0(\%)$ & & $5(\%)$ & & $0(\%)$ & & $0(\%)$ & & $0(\%)$ & \\
\hline
\end{tabular}

Note:

Pred $=$ prediction

$\mathrm{H}=$ Health, $\mathrm{G}=$ Grey, and F = Bankrupt.

After discussing the findings from the five bankruptcy prediction models, the study proceeds to discuss the impact of the bankruptcy prediction scores to the stock prices of the coal mining companies in Indonesia. However, as stated earlier, before estimating the relationship between the bankruptcy prediction scores and the stock prices, we need to evaluate first which panel regression model, the CEM, FEM or the REM is the most suitable model to estimate the relationship by using the Chow test and Haussmann test. The study found that the $\mathrm{p}$-value of the Chow test is insignificant $(p>0.05)$, indicating that the CEM is the most suitable model to estimate. Since the CEM is selected, thus the study did not need to further conduct the Haussmann test to select either the FEM or REM to be used as the best model as the finding from Chow test has confirmed suggesting the CEM as the most suitable model to estimate the impact of the bankruptcy prediction scores to the stock prices of the coal mining companies in Indonesia. 
Table 3. Findings from the Panel Multiple Regression

\begin{tabular}{lccc}
\hline Variables & CEM & FEM & REM \\
\hline Constant & $6.3345^{* * *}$ & $6.3334^{* * *}$ & $6.3334^{* * *}$ \\
Ohlson Score & $-0.0197^{* * *}$ & $-0.0197^{* * *}$ & $-0.0197^{* * *}$ \\
Almant-M Score & $0.1698^{* * *}$ & $0.1698^{* * *}$ & $0.1698^{* * *}$ \\
Grover Score & $-0.0343^{* *}$ & $-0.0343^{* *}$ & $-0.0343^{* *}$ \\
Springate Score & -0.0002 & -0.0002 & -0.0002 \\
Zmijewski Score & $0.0317^{* * *}$ & $0.0319^{* * *}$ & $0.0317^{* * *}$ \\
\hline $\mathrm{R}^{2}$ & 0.2635 & 0.2635 & 26.353 \\
F-Statistic & $19.6093^{* * *}$ & $11.6296^{* * *}$ & $23.6171^{* * *}$ \\
\hline
\end{tabular}

Note: ${ }^{* *}$ and ${ }^{* *}$ indicate significance at the $1 \%$ and $5 \%$ levels.

As observed from Table 3, the study found that the bankruptcy prediction scores of different models have different effects on the stock prices. However, overall, these prediction scores simultaneously affected the stock prices at the $1 \%$ significant level $(F$-value $=19.60934$, $p<0.01)$. This finding showed that the bankruptcy prediction score estimated using different models could predict the movements of the stock prices. Thus, the investors, managers, and policy makers could use the combination of these models at the same time to predict and stabilize the stock prices of the coal mining companies in Indonesia. This finding was consistent with the earlier studies by Amaliawiati and Lestari (2014), Andriawan and Salean (2016), and Adrian and Khoiruddin (2014) who documented that the bankruptcy prediction scores significantly affected the stock prices of the telecommunication companies.

However, if each model used to predict the stock price changes partially, the finding would be different, where not every model has prediction power to estimate the changes in stock prices in the future. This indicates that to get a better picture on the stock price movements, all models need to be considered at the same time when predicting the stock prices of the coal mining companies in Indonesia.

As for the findings for the partial relationships, the Springate prediction score was found to insignificantly affected the stock prices, the findings that contradict Effendi et al. (2016) who documented the significant effect of the Springate score on the stock prices. Meanwhile, the Ohlson and Grover prediction scores negatively and significantly affected the stock prices of the mining companies in Indonesia at the 1\% and 5\% levels of significance, respectively. This indicates that the higher these prediction scores, the stock price would decline, and vice versa.

On the other hand, the Almant modification and Zmijewski prediction scores positively affected the stock prices at the levels of $1 \%$ and $5 \%$, respectively. This implies that the higher these prediction scores, the higher would be the stock prices. The positive and significant effect of the Almant prediction score on the stock prices is in harmony with the previous studies on the Indonesian manufacturing companies (Adrian and Khoiruddin (2014), the pharmacy companies (Andriawan and Salean (2016), and the transportation companies (Amaliawiati 
and Lestari (2014). Meanwhile, the insignificant effect of the Springate prediction score on the stock prices is in line with the study by Wulandari and Norita (2014).

The different findings across the bankruptcy prediction models were simply due to different measurements used to predict the company's bankruptcy. These findings further imply that the bankruptcy prediction models have different levels of accuracy in predicting the performance of the firms. Thus, in predicting the performance of the firms, the investors, managers, and for policy makers should not only rely on a single bankruptcy model to predict the performance of the firm.

Our empirical findings on the relationships between the bankruptcy prediction scores and stock prices offer policy implication to the investors, managers, and regulators. For the investors, they might choose any significant models to analyse the companies' performances, but the Almant modification and Ohlson model are found to be the best models used to avoid the loss for investing monies in the coal mining industry in Indonesia. As for the regulators, particularly the Financial Service Authority of Indonesia should rely on the bankruptcy prediction scores to control the performances of the stock prices of the coal mining companies, as part of ensuring the stability of the national stock market. Similarly, manager of the companies might also promote the performances of the firms by referring to the bankruptcy prediction score as the sources of policy references.

\section{Conclusion}

The bankruptcy prediction models offer different findings of the performances of the coal mining companies in Indonesia over the period 2013-2015. The Grover model found the largest number of companies in the healthy category, while the Olhson model documented more firms in the bankruptcy category. Meanwhile, the Modified Almant model found more firms in the grey area category. As for the relationships between the bankruptcy predictions scores and stock prices, the study found that the Springate prediction score was insignificantly affected the stock prices. Meanwhile, the Ohlson and Grover prediction scores are found to affect negatively and significantly the stock prices of the mining companies in Indonesia, indicating that the higher these prediction scores, the lower would be the stock prices, and vice versa. On the other hand, the Almant modification and Zmijewski prediction scores are found to positively affect the stock prices, implying the higher these prediction scores, the higher would be the stock prices.

These findings further suggest that the investors should give more attention to the Ohlson and Grover models, because they gave negative prediction towards the stock prices. This means that when these models' prediction value is at one point in a company, then there would be a stock price reduction at one point in the future. As for the regulators, particularly the Financial Service Authority of Indonesia, it is suggested to rely on the bankruptcy prediction scores to control the performances of the stock prices, and in turns, the stability of the national stock market. Finally, the manager of the companies might also promote the performances of the firms by referring to the bankruptcy prediction score as the sources of policy references. To provide more comprehensive findings, future studies on this issue are 
suggested to consider more companies across the industries to be used as the sample of the study since different sector of industries has different characteristics. Additionally, future studies are also suggested to use a longer period of data so that it could provide a clearer picture of the bankruptcy prediction-stock prices relations.

\section{References}

Adrian, A., \& Khoiruddin, M. (2014). Pengaruh Analisis Kebangkrutan Model Altman Terhadap Harga Saham Perusahaan Manufaktur (The Impact of Altman Prediction Model to Stock Prices in Manufacturing Companies). Management Analysis Journal. Vol. 3(1): 1-14.

Al-Kassar, T. A., \& Soileau, J. S. (2014). Financial Performance Evaluation and Bankruptcy Prediction (Failure) 1. Arab Economic and Business Journal. Vol. 9(2): 147-155.

Al-Rawi, K., Kiani, R., \& Vedd, R. R. (2011). The Use of Altman Equation for Bankruptcy Prediction in an Industrial Firm (Case Study). International Business \& Economics Research Journal. Vol. 7(7): 115-127.

Altman, E. I. (1968). Financial Ratios, Discriminant Analysis and The Prediction of Corporate Bankruptcy. The Journal of Finance. Vol. 23(4): 589-609.

Altman, E. I., Iwanicz-Drozdowska, M., Laitinen, E. K., \& Suvas, A. (2017). Financial Distress Prediction in an International Context: a Review and Empirical Analysis of Altman's Z-Score Model. Journal of International Financial Management \& Accounting. Vol. 28(2): 131-171.

Amaliawiati, L., \& Lestari, L. (2014). The Prediction of Financial Distress Analysis and Its Implication to Stock Price's Sub-Sector Transportation in Indonesia Stock Exchange Period 2007-2011. Paper presented at the 11th Ubaya International Annual Symposium on Management, Surabaya.

Andriawan, N. F., \& Salean, D. (2016). Analisis Metode Altman Z-Score Sebagai Alat Prediksi Kebangkrutan dan Pengaruhnya Terhadap Harga Saham Pada Perusahaan Farmasi yang Terdaftar di Bursa Efek Indonesia (The Analysis of Altman Z-Score as Prediction Tools of Bankruptcy and The Impact of Stock Prices of Pharmautical Companies in Indonesian Stock Exchange). JEA 17. Vol. 1(1): 67-82.

Boedi, S., \& Tiara, D. (2016). Analisis Prediksi Kebangkrutan Perusahaan Telekomunikasi yang Terdaftar di Bursa Efek Indonesia Dengan Model Altman Revisi (Prediction Analysis of Bankruptcy of Telecommunication Companies Listed on Indonesia Stock Exchange with Altman Revision Model). Jurnal Manajemen dan Akuntansi (JUMA). Vol. 14(1): 63-70.

Charitou, A., Dionysiou, D., Lambertides, N., \& Trigeorgis, L. (2013). Alternative Bankruptcy Prediction Models Using Option-Pricing Theory. Journal of Banking and Finance. Vol. 37(7): 2329-2341.

Effendi, E., Affandi, A., \& Sidharta, I. (2016). Analisa Pengaruh Rasio Keuangan Model Springate Terhadap Harga Saham Pada Perusahaan Publik Sektor Telekomunikasi (The Effect of Financial Ratios Springate Models to Stock Prices in Telecomunication Public Companies). Jurnal Ekonomi, Bisnis \& Entrepreneurship. Vol. 10(1): 1-16. 
Grover, J., \& Lavin, A. (2001). Financial Ratios, Discriminant Analysis and The Prediction of Corporate Bankruptcy: a Service Industry Extension of Altman's Z-Score Model of Bankruptcy Prediction. Working Paper. Southern Finance Assosiation Annual Meeting.

Gunawan, B., Pamungkas, R., \& Susilawati, D. (2016). Perbandingan Prediksi Financial Distress Menggunakan Model Altman, Grover dan Zmijewski (The Comparation of Financial Distress Prediction Using Altman, Grover, and Zmijewski Model. Jurnal Akuntansi dan Investasi. Vol. 18(1): 119-127.

Hernandez-Tinoco, M., \& Wilson, N. (2013). Financial Distress and Bankruptcy Prediction Among Listed Companies Using Accounting, Market and Macroeconomic Variables. International Review of Financial Analysis. Vol. 30(Supl. C): 394-419. DOI: https:// doi.org/10.1016/j.irfa.2013.02.013

Hillegeist, S. A., Keating, E. K., Cram, D. P., \& Lundstedt, K. G. (2004). Assessing The Probability of Bankruptcy. Review of accounting studies. Vol. 9(1): 5-34.

Hussain, F., Ali, I., Ullah, S., \& Ali, M. (2014). Can Altman Z-score Model Predict Business Failures in Pakistan? Evidence from Textile Companies of Pakistan. Journal of Economics and Sustainable Development. Vol. 5(13): 110-115.

Jayasekera, R. (2017). Prediction of Company Failure: Past, Present and Promising Directions for The Future. International Review of Financial Analysis. Vol. 55: 196-208. DOI: https/doi.org/10.1016/j.irfa.2017.08.009.

Karamzadeh, M. S. (2013). Application and Comparison of Altman and Ohlson Models to Predict Bankruptcy of Companies. Research Journal of Applied Sciences, Engineering and Technology. Vol. 5(6): 2007-2011.

Karas, M., \& Režňáková, M. (2015). Predicting Bankruptcy Under Alternative Conditions: The Effect of a Change in Industry and Time Period on The Accuracy of The Model. Procedia-Social and Behavioral Sciences. Vol. 213: 397-403. DOI: https//doi. org/10.1016/j.sbspro.2015.11.557.

Ko, Y.-C., Fujita, H., \& Li, T. (2017). An Evidential Analysis of Altman Z-score for Financial Predictions: Case Study on Solar Energy Companies. Applied Soft Computing. Vol. 52: 748-759.

Marcinkevičius, R., \& Kanapickienè, R. (2014). Bankruptcy Prediction in the Sector of Construction in Lithuania. Procedia-Social and Behavioral Sciences. Vol. 156: 553-557. DOI: https://doi.org/10.1016/j.sbpro.2014.11.239.

Ohlson, J. A. (1980). Financial Ratios and The Probabilistic Prediction of Bankruptcy. Journal of Accounting Research. Vol. 18 (1): 109-131.

Pongsatat, S., Ramage, J., \& Lawrence, H. (2004). Bankruptcy Prediction for Large and Small Firms in Asia: a Comparison of Ohlson and Altman. Journal of Accounting and Corporate Governance. Vol. 1(2): 1-13.

Purnajaya, K. D. M., \& Merkusiwati, N. K. L. A. (2014). Analisis Komparasi Potensi Kebangkrutan Dengan Metode Z-score Altman, Springate, dan Zmijewski Pada Industri Kosmetik Yang Terdaftar di Bursa Efek Indonesia (Comparison Analysis of 
Bankruptcy Potency With Altman Z-Score, Springate, and Zmijewski Method in Cosmetic Companies That Listed in Indonesia Stock Exchange). E-Jurnal Akuntansi. Vol. 7(1): 48-63.

Putera, F. Z. Z. A., Swandari, F., \& Dewi, D. M. (2017). Perbandingan Prediksi Financial Distress Dengan Menggunakan Model Altman, Springate dan Ohlson (The Financial Distress Comparison Using Altman, Springate and Ohlson Model). Jurnal Wawasan Manajemen. Vol. 4(3): 217-230.

Rachmawati, T. (2016). Analisis Kebangkrutan Dengan Menggunakan Model Altman Z-Score Pada Perusahaan Asuransi Yang Go-Public di Bursa Efek Indonesia: Periode tahun 2010-2013 (Bankruptcy Analysis Using Altman Z-Score Model In Insurance Public Companies: Period of 2010-2013. Jurnal Ekonomi dan Bisnis. Vol. 17(1): 61-74.

Rahayu, F., Suwendra, I. W., \& Yulianthini, N. N. (2016). Analisis financial distress dengan menggunakan metode Altman Z-Score, Springate, dan Zmijewski pada perusahaan telekomunikasi. Jurnal Jurusan Manajemen, 4(1), 1-13.

Sembiring, E. E. (2016). Analisis Keakuratan Model Ohlson Dalam Memprediksi Kebangkrutan (delisting) Perusahaan yang Terdaftar di BEI (The Accuracy Analysis of Ohlson Model in Bankruptcy Prediction at Companies Listed in IDX). Jurnal Akuntansi Keuangan dan Bisnis. Vol. 9: 1-9.

Springate, G. L. (1978). Predicting the Possibility of Failure in a Canadian firm. (Unpublished Thesis). Britisch Columbia, Canada: Simon Fraser University.

Sudiyatno, B., \& Puspitasari, E. (2010). Tobin's Q dan Altman Z-Score Sebagai Indikator Pengukuran Kinerja Perusahaan (Tobin's Q and Altman Z-Score as Company's Performance Indicator). Jurnal Ilmiah Kajian Akuntansi. Vol. 2(1): 9-21.

Wu, Y., Gaunt, C., \& Gray, S. (2010). A Comparison of Alternative Bankruptcy Prediction Models. Journal of Contemporary Accounting \& Economics. Vol. 6(1): 34-45. DOI: https://doi.org/10.1016/jcae.2010.04.002.

Wulandari, A. P., \& Norita, A. I. (2014). Pengaruh Prediksi Kebangkrutan Ohlson Score (O-score) Terhadap Return Saham: Studi Pada Perusahaan Sub-Sektor Tekstil dan Garmen yang Listing di BEI tahun 2010-2014 (The Effect of Ohlson Score (O-Score) Bankruptcy Prediction to Stock Return: Study at Textile and Garments Companies Listed in IDX Period 2010-2014). e-Proceeding of Management 3(1), 101-108.

Xu, M., \& Zhang, C. (2009). Bankruptcy Prediction: The Case of Japanese Listed Companies. Review of Accounting Studies. Vol. 14(4): 534-558. DOI: https//doi.org/10.1007/ s11142-008-9080-5.

Yunan, Z.Y., \& Rahmasari, M. (2015). Measurement of Shariah Stock Performance Using Risk Adjusted Performance. Al-Iqtishad: Jurnal Ilmu Ekonomi Syariah (Journal of Islamic Economics). Vol. 7 (1): 127-140. DOI: https://doi.org/10.15408/aiq.v7i1.1364.

Zmijewski, M. (1983). Predicting Corporate Bankruptcy: An Empirical Comparison of The Extant Financial Distress Models. Document de travail. State University of New York at Buffalo. 